\title{
IJELTAL
}

\section{Evaluating EAP Textbooks for Indonesian University Students Using Impressionistic and In-depth Assessment}

\author{
Imroatus Solikhah \\ State Islamic Institute (IAIN) of Surakarta, Indonesia \\ e-mail:iimqueenoslo@gmail.com
}

\begin{abstract}
:
This study was qualitative content analysis that evaluated the quality of English for University Teaching (EUT), English for Specific Purposes (ESP), and English for Academic Purposes (EAP) textbooks through impressionistic and in-depth analysis. The participants were g EAP teachers and 15 EAP students from three universities in Surakarta, Indonesia. Instruments to collect data were checklist and interview guide. The checklist consisted of impressionistic analysis to see (1) cover, (2) content scope, (3) learning activities, (4) book organization, and (5) layout; and the indepth analysis, namely (1) aim and approach, (2) organization design, language and content, (3) language skills, and (4) practical consideration. Data were collected using checklist and Focus Group Discussion. Data were analyzed through summative content analysis with seven stages: transforming data into narrative text, determining unit of analysis, developing categories, coding, coding the entire text, checking consistency of coding, and drawing conclusion. Results show EUT and ESP have low quality based on the impressionistic evaluation, and fair quality of their in-depth evaluation. Both books are register and grammar oriented. EAP textbook is good in general, and very good in depth. EAP presents its contents in terms of genre reading, academic speaking, academic reading, academic writing and grammar.

Keywords: English for Academic Purposes, impressionistic, in-depth evaluation, textbook
\end{abstract}

\section{Introduction}

The role of a textbook in the teaching of English for Academic Purposes (EAP) is prominent. Some studies indicate that textbooks are the primary sources of teaching (Montasser, 2013), and textbooks make the available knowledge easy and organized in teaching (Hutchinson \& Torres, 1994). A textbook guarantee similar contents can be provided to students in different 
classes because the book contents can be evaluated at the same way (Richards, 2001). A textbook, therefore, functions as the structure of a learning program and a syllabus of teaching (Richards, 2001).

This paper investigates quality of EAP textbooks used in three universities in Surakarta that offer EAP as a compulsory course. EAP as the compulsory course has been served for students from various majors in the university, but a standard EAP textbook has not yet been welldeveloped. Solikhah $(2014,2015)$ has identified that EAP teaching materials are not based on the needs analysis and the contents of the books vary from one program to another depending on the teachers' perspectives.

A deliberate survey on the use of EAP textbooks used in universities indicate that contents of the EAP books focus more on grammar and register (Solikhah, 2014), the aims of the textbook are to equip students with TOEFL test preparation (Sheldon, 1988); and the books are designed by the lecturers to match their own needs (Dubin \& Olshtain, 1986). A textbook provides the outline for teachers to reach the course goals and objectives and serves as the lesson manual, however, the quality of the textbooks remains unfocused (Montasser, 2013). Hycroft (1998) admits textbooks gives the primary advantages that textbooks can help students show their learning progress and achievement that can be measured through the use of the textbooks.

Results of observation on the EAP classes and discussion to the EAP managers in various universities show two different perspectives. First, EAP is the potential class to equip students with basic English skills. This way, the main objective is to prepare students with reading skills, grammar competence, and TOEFL test preparation. In this perspective, students need a standard EAP textbook that are available in the markets, such as TOEFL Book, Academic Writing and a compilation textbook developed by the EAP teachers (Cunningsworth, 1984). Second, EAP class is a class that serves students with the academic literacy where speaking and writing are the basic needs. This program requires a textbook whose coverage include academic speaking presentation and academic writing. No matter what EAP choice is served, the textbooks used are of two kinds: the selected textbook available in the markets, and the teacher-made EAP textbooks, that contain a compilation of teaching materials the teachers deem appropriate to meet their needs (Ellis, 1997).

This paper argues that the need of a textbook in EAP teaching is compulsory in order to make the teaching materials standard. However, the selection of the textbook has become problematic as the aims of EAP in the universities vary from one university to another. The problems of a textbook selection vary. Textbooks have contributed required needs and inputs subjects in the classroom that can be performed from distinctive activities, reading texts and explanations (Hutchinson \& Torres, 1994), but the book quality varies differently. In addition, a textbook may appear as the syllabus of teaching, but the way the contents are applied in teaching has been affected by the students' competence (Montasser, 2013). Teaching settings in this context indicate different backgrounds that are unique to Indonesian EFL learners, different student abilities and needs, the criteria to which textbook selection is applied will inevitably vary (Broadfoot, et al. 1990).

To determine the quality of the textbook in this study, the researcher focuses on the textbook evaluation. Evaluation is defined as "the act of considering something to decide how useful or valuable (Longman Dictionary of Contemporary English, 2004). Textbook evaluation, 
"involves measuring the value or (potential value) of a set of learning materials by making judgments about the effect of the materials on the people using them" (Masuhara \& Tomlinson, 2008). The major aim of textbook evaluation is to adopt a new course book. Through the evaluation, the teacher can identify particular strengths and weaknesses in the textbooks already in use (Cunningsworth, 1984). According to McGrath (2001) the textbook evaluation basically explains the discovery of what you find in the book. Though 'Perfect book does not exist', the book evaluation provides the best possible opportunity to find the fixed materials that match to a particular learner group.

The materials evaluation process, according to Tomlinson (1996) has two concerns: to see the development of understanding in the classroom as how the books work, and to show how acquisition and pedagogical practices are applied. Cunningsworth (1995) sees that textbooks have several functions, namely as a learning source and effective to activate self-acquisition, for comprehensive material, a source of ideas and activities, student reference source, and a syllabus. Sheldon (1988) emphasized textbooks represent the visible core of the program, and give the cornerstone benefits to teacher and students. For Rea-Dickins and Germaine (1994), inherent part of teaching and learning is the evaluation. Cunningsworth (1995) argued that the textbook materials selected should represent learners' needs and goals, the method and the teaching program values. Ellis (1997) warned that textbook evaluation undergoes impressionistic assessments and helps acquire useful, accurate, systematic and contextual insights into the overall nature of textbook material.

Cunningsworth (1995) divides book evaluation into impressionistic evaluations (cursory) and in-depth evaluations (in-depth). Impressionistic assessment is done by observing the book cover, looking for the strengths and weaknesses of the book. Quick impressionistic assessments give an impression of the design and structure of the textbook, how attractive the book cover is, what additional material is presented, and what is the order of the book content. The assessment is based on a checklist that details the language function for the learner. Language is divided into units and subunits and phonological aspects such as vocabulary, grammar, discourse to determine the level of difficulty of the material. According to Cunningsworth (1995) the impressionistic method analyzes a general impression that include reading the blurb, contents page and skimming through the book to get a sense of organization, topics, layout and visuals. This method is not adequate in itself. The in-depth method focuses on a deliberate examination of characteristics of criteria, representing the design of a specific chapter or exercise, or the techniques of specific element of English. This method, however, has a drawback in that the unit being selected could not obviously represent the whole book contents (Sahim, 2020; Monbec, 2020).

When selecting a textbook, some considerations should be taken into account. McGrath (2001) listed the learner and teacher factors. The learner factors are the range of age of students, level of competence in English, reasons to learn English, and gender. Learners factor indicate the needs of the learners, namely sample dialect, focus of the language-skills, focus of language-system (i.e. grammar, vocabulary, phonology) and mechanic aspects (spelling, punctuation) (Rahimy, 2007; Peacock, 1997). Teacher factors include English competence, competence in methodology, awareness, and teaching experience. In addition, specific program of the materials to whom it is addressed, e.g. pre-school, primary, secondary school, class number, goals and objectives, and syllabus are also prominent information to consider (Lawrence, 2011; Yacipi, 2019; Ur, 1996). 


\subsection{Research Questions}

Drawing from the rationale and background above, two research questions were developed to guide the research process. The research questions are:

1) What impressionistic evaluation is indicated to show the quality of EAP textbooks used in the universities in Surakarta?

2) What in-depth evaluation has been demonstrated in the quality of EAP textbooks used in the universities at Surakarta?

\section{Research Methodology}

\subsection{Design}

This study applied content analysis design the aim of which was to evaluate EAP textbooks. Three EAP textbooks evaluated in this study were: English for University Teaching (EUT), English for Specific Purposes (ESP), and English for Academic Purposes (EAP). The focus of evaluation is the quality of the textbooks from which impressionistic and in-depth analysis were done (Cunningsworth, 1995). Contents analysis examined documents, text, or speech to see what themes emerged (Zhang \& Barbara, 2016) that focused on unique themes that illustrated the range of the meanings of the phenomenon of particular texts or concepts (Hsieh and Shannon (2005). It condensed raw data into categories or themes inductively, by which themes and categories emerge from the data through the researcher's careful examination and constant comparison (Patton, 2002). The focus of qualitative content analysis are language as communication specified to the content or contextual meaning of the text (Tesch, 1990). Text data included verbal, print, or electronic form revealed from narrative responses, open-ended survey questions, interviews, focus groups, observations, or print media such as articles, books, or manuals (Kondracki \& Wellman, 2002). Following Hsieh and Shannon (2005), among three approaches to qualitative content analysis: conventional content analysis, directed content analysis, and summative content analysis, the researcher applied the summative content analysis. Stages of a summative content analysis include calculating the words or manifest content, and applying the analysis to find substantial meanings and themes. At the early stage, this approach uses quantitative analysis, but it aims to elaborate inductively the word usage the usage as prescribed as the indicators.

\subsection{Participants}

Participants of this research were 9 EAP teachers in three universities in Surakarta and 15 students joining in EAP classes. The universities in this study were identified as Uni 1, Uni 2, and Uni 3 each of which operated EAP classes through their language center. The participants were recruited based on the purposes sampling (Lawrence, 2011). The 9 EAP teachers were selected as they were the permanent teachers in the universities and some were responsible to manage the EAP program. In addition, students of the EAP classes that used the textbooks being analyzed in this study were recruited allowing 5 students from each university. Table 1 shows the characteristics of the participants of this study. 
Table 1. Participants of the Study

\begin{tabular}{|c|l|c|c|}
\hline No & University & Number & $\mathbf{\%}$ \\
\hline 1 & Uni 1 & & \\
\hline & EAP Teacher & 3 & 12.5 \\
\hline & EAP Students & 5 & 20.8 \\
\hline 2 & Uni 2 & & \\
\hline & EAP Teacher & 3 & 12.5 \\
\hline & EAP Students & 5 & 20.8 \\
\hline 3 & Uni 3 & 3 & 12.5 \\
\hline & EAP Teacher & 5 & 20.8 \\
\hline & EAP Students & $\mathbf{2 4}$ & $\mathbf{1 0 0}$ \\
\hline & & & \\
\hline
\end{tabular}

\subsection{Research Instrument}

This study employed two research instruments to collect data: checklist and interview guide. The primary instrument was a check list to evaluate the textbook quality. The checklist adopted model from Cunningsworth (1995) that examined quality of a textbook based on impressionistic analysis and the in-dept analysis. Cunningsworth (1995) developed the checklist as follows: The impressionistic analysis is focused on: (1) cover, (2) content scope, (3) learning activities, (4) book organization, and (5) layout. The in-depth analysis covers: (1) aim and approach, (2) organization design, language and content, (3) language skills, and (4) practical consideration. This checklist was used to evaluate through cintent analysis the quality of each texbook. The second instrument was interview guide (Sahim, 2020; Monbec, 2020). After the content quality of each textbook was identified, the researcher confirmed with participants opining the results of the content evaluation. To be practical, items of the checklist were replicated for use. Based on the items, the researcher was able to elaborate participants' opinion and argument to define the quality of the textbooks (Oakey, 2020, Mukundan, et al, 2011).

\subsection{Data Collection Procedure}

Data of this study were of two kinds: results of checklist evaluation and results of verbal information representing participants' opinion. Data of the checklist evaluation were collected by applying the checklist to assess the quality of each textbook (Okitasari \& Palupi, 2019; Mukundan et al, 2011). Firstly, each textbook was read thoroughly by the researcher then the impressive checklist was applied to evaluate. The researcher received assistance from two collaborators who helped evaluate the textbooks. Together with the collaborators, the researcher conducted the impressionistic evaluation by giving scores on the general quality of the textbook. Secondly, the researcher focuses on the details of the textbook contents and applied the checklist to assess the quality. Together with the collaborators, the researcher scored each component of the book quality, then the researcher discussed the results to find the final score of each textbook. In doing the assessment, the researcher and the collaborators worked on one textbook at the same time, and after the assessment of the same textbook finished, the second turn was done to see the second textbook and so as to the third textbook. This method allowed the researcher to validate the trustworthiness of 
data through member check method (Zhang \& Barbara, 2016; Ramadhana, 2019; Purwati, 2019).

After the data of checklist has been finalized, the researcher and the collaborators brought the data into the Focus Group Discussion (FGD) with 9 EAP teachers and 15 EAP students. Through FGD the researcher discussed the results of evaluation checklist, confirmed the findings and identified evidences that dissented with the evaluation results. To record the discussion during FGD, the researcher worked with two collaborators to audio-tape, to make the field note, and to memo the process. The results of recorded discussion were transcribed verbatim, and results of the field notes and memos were confirmed. This way, the method triangulation that collected data from various sources and techniques were done.

\subsection{Data Analysis Techniques}

To analyze the data, this study used a summative content analysis (Hsieh \& Shannon, 2005; Zhang \& Barbara, 2016), and applied an inductive analysis (Patton, 2002). The summative content analysis examined the quantitative data at the beginning then went to the qualitative data that involved themes and inferences of the whole data. The analysis process included seven steps, whereby transforming any data into written text took as the first step. Secondly, unit of analysis was set, identifying messages into the units, where each unit was coded (De Wever et al, 2006). In the third step, categories were developed, and a coding scheme as a manual was administered. Weber (1990) asserts the manual involved category name, coding for definitions or rules, and instances. The fourth stage served testing the coding scheme to the instance by checking the codes in the instance, checking consistency of coding, and revising rules of the coding to gain appropriate consistency of the coding (Weber, 1990). Fifth, entire corpus of the text all were coded until sufficient consistency has been achieved. Sixth, assessing the coding consistency involved rechecking the coding of the entire data set. Seventh, drawing conclusion from the coded data by making sense of the themes or categories and their attributes, making inferences and presenting reconstruction of meaning derived from the data.

Operationally, this study analyzed the data by preparing scores obtained from impressionistic and in-depth evaluation into the narrative texts (Zhang \& Barbara, 2016). Each point in the checklist was identified its score and the overall attributes were narrated in the written text. In addition, results of interview in the FGD, field notes and memos that supplemented the results of checklist were drawn in the narrative texts. Based on the narrative texts obtained from the transformation of the checklist into narrative text and the results of interview, field notes and memos, the unit of analysis was identified. The identification represented the items of impressionistic evaluation as well as the in-depth evaluation. Respectively, the unit of analysis was coded, the coding was tested its consistency, until all texts received their own coding. Verification of the final coding was confirmed whether the analysis has confirmed to answer the research questions of this study (Kulm, Roseman, Treistman, 1999; Sahim, 2020; Zhang \& Barbara, 2016).

\section{Findings}

This section reports the results of evaluation on the quality of three textbook: EUT, ESP, and EAP. Quality of the textbook is assessed using the impressionistic overview and an in-depth analysis. The impressionistic analysis focuses on (1) cover, (2) content scope, (3) learning 
activities, (4) book organization, and (5) layout. The in-depth analysis covers (1) aim and approach, (2) organization design, language and content, (3) language skills, and (4) practical consideration.

\subsection{Text Book 1: English for the University Teaching}

EUT is the primary textbook used in the language center 1 of the univerity 1 in this researc. Profile of textbook 1 as seen from the table of contents is indicated as in table 2.

Table 2. Table of contents of EUT

\begin{tabular}{|c|l|c|}
\hline No & \multicolumn{1}{|c|}{ Topic } & Page \\
\hline 1 & Noah Webster & $1-10$ \\
2 & Family planning in the 21st century & $11-20$ \\
3 & Life in the digital era & $21-28$ \\
4 & Women's Role in Industrial Specialties & $29-36$ \\
5 & Intercultural as an academic literacy & $37-44$ \\
6 & The role digital literacy in the global era & $45-52$ \\
7 & Disruptive information & $53-62$ \\
8 & Food Preservation & $63-72$ \\
9 & New Apartment for Fishermen & $73-80$ \\
10 & Air Pollution & $81-90$ \\
\hline
\end{tabular}

Based on the table of content of the book, general evaluation that stresses on impressive evaluation is done. The results appear in table 3.

Table 3. General Evaluation of EUT

\begin{tabular}{|c|l|l|c|}
\hline No & $\begin{array}{l}\text { Aspects to } \\
\text { Evaluate }\end{array}$ & Results of Evaluation & $\begin{array}{l}\text { Final } \\
\text { Results }\end{array}$ \\
\hline 1 & Cover & $\begin{array}{l}\text {-Fair } \\
\text {-ISBN and publisher are credible }\end{array}$ & Fair \\
\hline 2 & Content scope & $\begin{array}{l}\text {-Learning objectives are specified } \\
\text {-Focus is specified in reading and grammar } \\
\text {-Exercises are availeble in terms of reading \& } \\
\text { grammar }\end{array}$ & Good \\
\hline 3 & $\begin{array}{l}\text { Learning activities } \\
\text { to develop }\end{array}$ & $\begin{array}{l}\text {-Vary from reading, vocabulary, grammar } \\
\text {-Activities to develop other skills are not available }\end{array}$ & Good \\
\hline 4 & Organization & $\begin{array}{l}\text {-Well-developed } \\
\text {-Sequence from easy to hard is set }\end{array}$ & Good \\
\hline 5 & Layout & $\begin{array}{l}\text {-Good } \\
\text {-Chapters and sub-chapters are consistently } \\
\text { developed }\end{array}$ & Good \\
\hline
\end{tabular}

As table 3 suggests, in general EUT has two charactertsitics. It has a fair cover, and good content scope. Further an-indepth analysis of EUT is presented in table 3. The results of analysis show that of 5 aspects, cover receives fair catetory, and content scope, larning acrivitoes, organization and layout indicate good category. Further, the indepth analysis of EUT appears in table 4 . 
Table 4. Indepth evaluation of EUT textbook

\begin{tabular}{|c|l|l|c|}
\hline No & \multicolumn{1}{|c|}{$\begin{array}{c}\text { Aspects to } \\
\text { Evaluate }\end{array}$} & \multicolumn{1}{|c|}{ Indicators } & Category \\
\hline 1 & $\begin{array}{l}\text { Aims (General } \\
\text { objective) }\end{array}$ & $\begin{array}{l}\text { To develop reading ability and grammar } \\
\text { mastery }\end{array}$ & Good \\
\hline 2 & Specific Objectives & $\begin{array}{l}\text {-To develop language functions } \\
\text {-To provide basic skills of English } \\
\text { language in university level }\end{array}$ & Good \\
\hline 3 & $\begin{array}{l}\text { Design \& } \\
\text { Organization }\end{array}$ & $\begin{array}{l}\text {-Reading, grammar and exercises } \\
\text {-Materials are graded heirarcically }\end{array}$ & Good \\
\hline 4 & $\begin{array}{l}\text { Skills } \\
\text {-Reading } \\
\text {-Basic knowledge of English berupa } \\
\text { grammar dan vocabulary }\end{array}$ & $\begin{array}{l}\text { Conclusion } \\
\text { affordability }\end{array}$ & \begin{tabular}{l}
-Practical, available in campus, affordable \\
\hline
\end{tabular} \\
\hline
\end{tabular}

As table 4 suggests, the results of the indepth analysis of EUT are elaborated as the following:

1) General Purpose

The general purpose of EUT is indicated from the comprehensive presentation of the contents of the book, the development of reading and grammar skills. The general purpose appears from the entire book content and the presentation of the chapter as a whole. This book is categorized as good because it includes reading, grammar and vocabulary.

\section{2) Specific Purpose}

The specific objectives of EUT are indicated from (1) developing language functions, and (2) developing basic English language skills. Language functions are the use of grammar and sentence examples. The presentation of the material begins with the reading text and then describes the grammar topic. These specific objectives are categorized as good.

\section{3) Design and Organization}

The EUT materials provide reading and grammar. Reading is equipped with practice questions, new vocabulary, exercises, answering reading questions and vocabulary. Grammar is followed by question exercises and enrichment exercises. Material is described consistently in each chapter in the book and qualifies for independent learning resources. The material is deep, coherent according to the level of difficulty, accompanied by training, and is consistent in its presentation so that the design and organization of the EUT content are categorized as good.

\section{4) Language Skills}

EUT provides reading skills. The language components of basic knowledge of English are vocabulary and grammar. Even though only reading skills were developed, the contents of the book were packaged with integrated exercises between reading, grammar, and vocabulary. This presentation is categorized as good. 
5) Practicality and Affordability

The book has been provided with ISBN (International Series of Book Number) and the publisher is legible. Book price is affordable for every student. Practicality and affordability of this book are categorized as very good.

\subsection{Text Book 2: English for Specific Purposes}

The second textbook to analyze is English for Specific Purposes (ESP) used as the primary textbook at the language center of university 2 . To start with, table of content of ESP appears in table 5 and general evaluation in table 6.

Table 5. Table of contents of ESP

\begin{tabular}{|c|l|c|}
\hline No & \multicolumn{1}{|c|}{ Topic } & Page \\
\hline 1 & The Simple Present Tense & $1-8$ \\
2 & ThePresent Continuous & $9-14$ \\
3 & Simple Past & $15-20$ \\
4 & The Simple Future Tense & $21-26$ \\
5 & The Present Perfect & $27-32$ \\
6 & The Basic Structure of Clause and Sentence & $33-36$ \\
7 & The Passive Voice & $37-42$ \\
8 & Scanning & $43-48$ \\
9 & Retailing & $49-54$ \\
10 & City Life & $55-60$ \\
11 & Keeping the Customer Satisfied & $61-66$ \\
12 & Who Wants to be a Millionaire & $67-74$ \\
13 & Company Structure & $75-84$ \\
14 & Money & $85-89$ \\
\hline
\end{tabular}

Based on table 5, we can see that ESP emphasizes grammar and reading material. Grammar nuances can also be seen from discussion of theories and exercises. The first seven units discuss grammar and the next seven topics are reading texts followed by text comprehension exercises.

Table 6. General evaluation of the ESP

\begin{tabular}{|c|c|c|c|}
\hline No & $\begin{array}{l}\text { Aspect to } \\
\text { Evaluate }\end{array}$ & Indicators & Category \\
\hline 1 & Cover & $\begin{array}{l}\text {-Interesting enough } \\
\text {-Publushed by the university }\end{array}$ & Fair \\
\hline 2 & Content scope & $\begin{array}{l}\text {-No learning objectives are defined } \\
\text {-Focused on grammar, grammar } \\
\text { exercises, reading passage and its } \\
\text { exercices }\end{array}$ & Fair \\
\hline 3 & $\begin{array}{l}\text { Learning activites } \\
\text { to develop }\end{array}$ & $\begin{array}{l}\text {-Limited variation, focused more on } \\
\text { grammar exercises } \\
\text {-No developing other skills }\end{array}$ & Fair \\
\hline 4 & Organization & -Well-developed for the grammar & Fair \\
\hline \multirow[t]{2}{*}{5} & Layout & $\begin{array}{l}\text {-Less interesting } \\
\text {-Monotonpus presentation }\end{array}$ & Fair \\
\hline & & Conclusion & Fair \\
\hline
\end{tabular}


Let us have a look at data on table 6 that indicates results of gerenal evaluation of ESP textbook. The results are elabirated below.

1) The ESP cover page is quite attractive, clear and has sufficient illustrations. However, the book size is small and thin, so this book is categorized as medium.

2) The content coverage is sufficient, because only two things are discussed: grammar and text. The orientation of this book is clearly towards grammar.

3) Learning activities developed were grammar as the main study and reading as an additional. No other skills. This section is categorized as sufficient.

4) Organization of the book content shows the chapters and sub-chapters presented in each unit. There are two sequences, the beginning of the grammar topic and the end of the reading. Such an organization is categorized as sufficient.

5) Layout which is a mechanical aspect, readability, and illustrations in the ESS are categorized as sufficient.

The general analysis of ESP shows insufficient results. The shortcomings of this book include: the content is more focused on grammar even though there is a reading text and the organization of the content is less consistent. In addition, the book is small, thin and the illustrations are less attractive. The advantage is that ESP is easy to obtain because it is selfprinted and at an affordable price.

The results of the in-depth analysis of the contents of the book showed that of the five aspects assessed, ESP got a score: insufficient, sufficient, sufficient, sufficient, and good. The general purpose of the contents of the book is categorized as lacking and the specific purpose is sufficient. Sufficient grades are indicated by aspects of design and organization, and language skills, respectively. Good value is shown by the practicality and affordability of the book. See Table 7 for the complete results of the in-depth ESP analysis.

As table 7 suggests, the results of indepth analysis of ESP are elaborated below:

1) General Purpose

The general objective of ESP is to develop the ability to master grammar and reading. The chapter structure that is presented starts from unit 1 to unit 7 in the form of a discussion of grammar theory. Furthermore, units 8 to 14 are in the form of reading texts. This general purpose is categorized as good.

Table 7. The indepth evauation of ESP

\begin{tabular}{|c|l|l|c|}
\hline No & Aspects to Evaluate & Indicators & Category \\
\hline 1 & $\begin{array}{l}\text { Aims (Tujuan } \\
\text { Umum/SK) }\end{array}$ & $\begin{array}{l}\text { To develop grammar mastery and reading } \\
\text { ability }\end{array}$ & Good \\
\hline 2 & $\begin{array}{l}\text { Objectives (Tujuan } \\
\text { Khusus/KD) }\end{array}$ & $\begin{array}{l}\text {-To develop the language usage } \\
\text {-To develop basic reading skills }\end{array}$ & Good \\
\hline 3 & $\begin{array}{l}\text { Design \& } \\
\text { Organization }\end{array}$ & $\begin{array}{l}\text {-Grammar-reading; reading-grammar } \\
\text {-Well developed and consistent }\end{array}$ & Good \\
\hline 4 & Skills & $\begin{array}{l}\text {-Reading } \\
\text {-Grammar }\end{array}$ & Good \\
\hline 5 & $\begin{array}{l}\text { Kepraktisan dan } \\
\text { keterjangkauan }\end{array}$ & $\begin{array}{l}\text {-Practical and affordable } \\
\text { Conclusion }\end{array}$ & Good \\
\hline
\end{tabular}


2) Specific Purpose

It can be seen in the description of each unit, the specific objectives of ESP are the development of language functions and mastery of the basics of reading English texts. Language functions can be seen in the description of grammar theory and deepening exercises, while the basics of reading written texts can be seen from exercises in comprehension questions, vocabulary, and exercises in deepening the understanding of text content and vocabulary use. This goal is categorized as good.

\section{3) Design and Organization}

The design and organization of the contents of the book are categorized as sufficient. The presentation of teaching materials is carried out coherently: first grammar then reading. Grammar material starts from grammar theory followed by mastery and deepening exercises. The reading material begins with the presentation of the discourse with different themes, then practice questions to deepen the content of the text followed by vocabulary exercises.

\section{4) Language Skills}

The language skills developed are reading and strengthening basic grammar and vocabulary skills. However, the presentation is not consistent in terms of the difficulty level of the ingredients presented. Grammar and reading topics are not integrated. This section is categorized as sufficient.

5) Practicality and Affordability

ESP turns out to have very high practicality and very high affordability because the book has been reprinted 14 times. This very high practicality occurs because the faculty requires all students to use ESP as a compulsory book. This section is categorized as very good.

\subsection{Textbook 3: English for Academic Purposes}

Table 8 shows the table of contents of the textbook of English for Academic Purposes (EAP).

Table 8. Table of content of the EAP

\begin{tabular}{|c|l|c|}
\hline No & Topic & Page \\
\hline 1 & Description & $1-16$ \\
2 & Report & $17-32$ \\
3 & Recount & $33-52$ \\
4 & Procedure & $53-70$ \\
5 & Explanation & $71-88$ \\
6 & Exposition & $89-106$ \\
7 & Discussion & $107-128$ \\
\hline
\end{tabular}

As table 8 suggests, the EAP deals with reading passage as the main materials, that indicates the use of genre approach. Genre approach develops learning activities through reading texts of various themes that represent the different scopes. Further analysis to evaluate general evaluation appears in table 9. 
Table 9. General evaluation of EAP

\begin{tabular}{|c|c|c|c|}
\hline No & $\begin{array}{l}\text { Aspects to } \\
\text { Evaluate }\end{array}$ & Indicators & Category \\
\hline 1 & Cover & $\begin{array}{l}\text {-Very interesting } \\
\text {-Published by the university press }\end{array}$ & Good \\
\hline 2 & Content scope & $\begin{array}{l}\text {-Focus on reading, grammar, variety of } \\
\text { exercices, and various learning activities }\end{array}$ & Very good \\
\hline 3 & $\begin{array}{l}\text { Learning activities } \\
\text { to create }\end{array}$ & $\begin{array}{l}\text {-Varied and interesting } \\
\text {-Varied learning activiies are available to } \\
\text { develop other skills }\end{array}$ & Very good \\
\hline 4 & Organization & $\begin{array}{l}\text {-Well-developed suported with } \\
\text { interesting learning activities }\end{array}$ & Very good \\
\hline \multirow[t]{2}{*}{5} & Layout & $\begin{array}{l}\text {-Very good, legible and well-designed } \\
\text {-Consistent chapter presentation }\end{array}$ & Very good \\
\hline & & $\begin{array}{l}\text { Conclusion } \\
\end{array}$ & Very good \\
\hline
\end{tabular}

Table 9 suggests the result of general evaluation of EAP, are elaborated, as follows:

1) EAP cover page, design and illustration is clear. Book display and colors are also good. So this section is categorized as good.

2) The content is diverse and can be used as a source of independent study material and independent training. The focus of the material varies from reading, speaking, language focus, grammar and other activities. This section is categorized as very good.

3) Learning activities are developed in various ways and can be used for the three skills learning model, speaking, reading, writing. This section is categorized as good.

4) Organization of the contents of the book, which contains the presentation of chapters and exercises, including being presented in a coherent manner, fulfills the elements of sequence and is consistent. This section is categorized as very good.

5) The layout which contains writing techniques, readability, illustration, and mechanics found in the EAP is categorized as very good.

Further, Table 10 describes the results of the indepth-analysis of EAP indcating the the quality of EAP is very good.

Table 10. Indepth evaluation of the EAP

\begin{tabular}{|c|c|c|c|}
\hline No & $\begin{array}{l}\text { Aspect to } \\
\text { Evaluate }\end{array}$ & Indicators & Category \\
\hline 1 & $\begin{array}{l}\text { Aims (General } \\
\text { objective) }\end{array}$ & $\begin{array}{l}\text { To develop the competence of reading, grammar and } \\
\text { speaking ability }\end{array}$ & Good \\
\hline 2 & $\begin{array}{l}\text { Specific } \\
\text { Objectives }\end{array}$ & $\begin{array}{l}\text {-To develop reading comprehension } \\
\text {-To acquire vocabulary, grammar, speaking, and writing } \\
\text {-To increase score of TOEFL } 450\end{array}$ & Very good \\
\hline 3 & $\begin{array}{l}\text { Design \& } \\
\text { Organization }\end{array}$ & $\begin{array}{l}\text {-Reading text, grammar, other language activities } \\
\text {-Good order and consistent }\end{array}$ & Very good \\
\hline 4 & Skills & $\begin{array}{l}\text {-Reading } \\
\text {-Speaking } \\
\text {-Grammar }\end{array}$ & Very good \\
\hline 5 & $\begin{array}{l}\text { Practicality and } \\
\text { affordability }\end{array}$ & -Practical, available at library, price is affodable & Very good \\
\hline & & Conclusion & Very good \\
\hline
\end{tabular}


As table 10 suggests, the results of indepth evaluation are elaborated below.

1) General Purpose

The general objective of EAP is the development of competency in reading, grammar and speaking. These competencies are the basic abilities required for students who are in their first year at university. This general purpose is categorized as good.

\section{2) Specific Purpose}

The specific purpose of EAP is contained in the presentation of material in each book unit. It appears in the description that the EAP has specific objectives for (1) developing reading competence, (2) mastery of vocabulary, grammar, speaking, and mastery of the TOEFL to achieve a score of 450 . This particular goal is categorized very good.

\section{3) Design and Organization}

The design and organization of the contents of the book are developed in a variety of ways, starting with general activities before entering the material, developing through reading the text, followed by integrated development exercises. This section is categorized as very good.

\section{4) Language Skills}

Because the variety of materials varies, in general, the contents of the EAP can be developed into four skills: listening, speaking, reading, and writing. Based on the text, language skills that can be developed explicitly are reading and speaking. In addition, enrichment in the form of language focus to study grammar, vocabulary and integrated exercises can be developed from a variety of learning activities. This section is categorized as very good.

5) Practicality and Affordability

In terms of practicality, the EAP is available on campus and easy to obtain. Book prices are also affordable. This section is categorized as very good.

\section{Discussion and Implication}

This study analyzes the results of impressionistic and in-depth evaluation of EAP textbooks. General evaulation of EAP textbooks show that grammar and reading are emphazied. In the in-depth evaluation, EAP textbooks under study indicates that language functions and the development of language activtites have been provided. Specifically, two books, that are EUT and ESP emphasize grammar and reading comprehension, and one, that is EAP emphasizes the achievement of four competency-based English language skills. EAP shows that the texts in each unit refers to the genre-approach, with the types of text description, recount, explanation, exposition, and procedure.

Based on the general evaluation, we can infer that EUT and ESP have low quality as the primary textbook of EAP teaching. The emphases of the books that provide grammar and reading as the main teaching contents, indicate that the books are grammar translation methods oriented. The in-depth analysis show that these books have been developed under register and grammar learning. Register learning emphasizes on specific terminology or terms in certain fields of science. Registers are taken from reading passages in the form of vocabulary. The lesson discusses grammar theories and exercises. This finding confirms 
characteristics of a textbook that orients in the study skills (Kulm, Roseman, Treistman, 1999; Cunningsworth, 1995; Griffiths, 1995).

The books also show that the learning variation is indicated by the use of skills and the target achievement is the TOEFL score. The learning emphasizes grammar, vocabulary, and reading. Classes tend to be dominated by grammar practice and practice TOEFL questions. The reading passage given is a text related to mastery of TOEFL material and the ability to answer TOEFL questions. This target is not in accordance with the nature of the EAP (Purwati, 2019; Oakey, 2020; Monbec, 2020).

From the FGD we found that reference textbooks are grammar or reading books and there are no special books. The learning focus follows the teaching lecturer design. The syllabus prepared by the lecturers that present different contents and targets of teaching showing that EAP teaching is differently perceived. Register learning emphasizes on specific terminology or terms in certain fields of science. Registers are taken from reading passages in the form of vocabulary. The lesson discusses grammar theories and exercises (Ur, 1996; Okitasasi \& Palupi, 2029).

In addition, EAP textbook shows that it integrates between reading comprehension ability and other skills that put emphasis on English competence. EAP provides learning activities that serve speaking, and writing skills from which academic literacy of the students are developed. Competency-based English learning is currently emphasized as the learning outcomes. Learning integrates register, skill-based and is based on an analysis of student needs. The focus of learning is study skills to achieve performative literacy for reading, writing and speaking. Textbooks are provided specifically for the purpose of developing academic abilities (Lawrence, 2011; Masuhara \& Tomlinson, 2008).

Analysis to both general and in-depth evaluation of textbooks under study prove that EUT and ESP do not include English competence that is currently in a trend model to achieve academic literacy (Sahim, 2020; Yacipi, 2019). EAP textbook, however, provides the competence as it serves reading for academic English, writing for academic English, and speaking for academic English. This finding confirms that the quality of textbook is very good (Masuhara \& Tomlinson, 2008), because it serves various learning activities that make students creative to develop their skills (Ur, 1996). Academic writing has been the target of EAP because writing is the basic academic literacy EFL students should achieve to make them success in the higher education (Oakey, 2020; Monbec, 2020).

Results of interview during FGD reveal that all participants indicate that when developing the textbooks, the author did not consider the students needs, so that needs assessment were not conducted. The findings dissent with the opinions of some experts (Ur, 1996; Mukundan, 2011; Sahim, 2020; Monbec, 2020; Lawrence, 2011) who claim that needs analysis is the primary requisite for teaching materials development including the textbook. Some features that indicate the shortage of the textbook because of the absence of the needs assessment include learning objectives are not well-developed nor the content scopes are properly sequenced. This finding confirms the study by Solikhah (2014; 2015). Solikhah (2014) indicates that EAP textbooks used in the state universities, such as UNS, UGM, UNY, UNDIP and UNSOED, are not based on the needs analysis. In addition, the only EAP textbook used in UNS applies competence-based learning outcomes from which the inclusion of the content scopes of the textbook has been deliberately developed. 
This study has showed that general evaluation of a textbook has guided quick information showing the general quality of a textbook. The general evaluation does not provide detail characteristics of the textbook. Elaboration on the in-depth evaluation in this study confirms that UET and ESP are short because the textbooks are register and grammar oriented. Learning activities are limited to occur in terms of reading comprehension and grammar exercises. Conversely, EAP has been well-prepared and the content scopes provide reading, speaking, grammar, and academic writing from which English competence is based upon relevant to academic literacy the students should attain in the university. This finding implies that textbooks that focus on register and grammar are not well-accepted for university textbooks. The textbook that includes English competence-based for the university students serve academic literacy contained in the content scopes such as academic writing, reading for academic purposes, speaking for academic, and academic vocabulary.

This study promotes its novelty that an in-depth evaluation of a textbook should include information on the process of inclusion of needs assessment before a textbook is developed. Checklist to evaluate the textbook needs newly adaptation to develop, relevant to local and global trends. This study suggests that checklist developed by Cunningsworth (1995) needs to be elaborated its items.

\section{Conclusion}

The aims of this study are to see impressionistic or general evaluation and in-depth evaluation checklist are applied to evaluate three EAP textbooks: EUT, ESP and EAP. The impressionistic analysis examines general characteristics of a book, (1) cover, (2) content scope, (3) learning activities, (4) book organization, and (5) layout. The in-depth analysis covers: (1) aim and approach, (2) organization design, language and content, (3) language skills, and (4) practical consideration. In general, the checklist is proper for the assessment need and reveals accurate information. EUT and ESP have been assessed as low quality as these book are characterized to serve their contents on register and grammar whereby learning activities are more focused to have reading comprehension and grammar exercises. In addition, EAP has been well-developed to integrate academic literacy in reading, speaking, and academic writing. Specifically, EAP has included the competence-based English proficiency in its content scopes and learning activities.

This study finds that some aspects of evaluation cannot be measured by the checklist. A suggestion is proposed that the items are elaborated in more number and more variations as in Mukundan (2011). Future research is recommended to contrast the results of evaluation that is based on the checklist with the perceptions of teachers and students.

\section{References}

Broadfoot, P., Murphy, R. and Torrance, H. (eds). (1990). Changing Educational Assessment: International Perspectives and Trends. London: Routledge.

Cunningsworth, A. (1984). Evaluating and selecting EFL teaching materials. London: Heinemann Educational Books.

De Wever, B., Schellens, T., Valcke, M., \& Van Keer, H. (2006). Content analysis schemes to analyze transcripts of online asynchronous discussion groups: A review. Computer \& 
Education, 46, 6-28.

Dubin, Fraida, and Elite Olshtain. (1986). Course design: Developing Programs and Materials for Language Learning. Cambridge: Cambridge University Press.

Ellis, Rod. (1997). The empirical evaluation of language teaching materials. ELT Journal, 51(1), pp. $36-42$

Griffiths, C. (1995). Evaluating materials for teaching English to adult speakers of other languages. Forum 33(3): 50. Retrieved from http://forum.state.gov/vols/vol33/ no3/p5o.htm

Hsieh, H.-F., \& Shannon, S.E. (2005). Three approaches to qualitative content analysis. Qualitative Health Research, 15(9), 1277-1288.

Hycroft, J. (1998). An Introduction to English Language Teaching. New York \& London: Longman.

Hutchinson, T and \& Torres, E. (1994). The Textbook as an Agent of Change. ELT Journal, 48(4).

Hutchinson, T. \& Waters, A. (1987). English for specific purposes: A learning-centered approach. Cambridge: Cambridge University Press.

Kondracki, N. L., \& Wellman, N. S. (2002). Content analysis: Review of methods and their applications in nutrition education. Journal of Nutrition Education and Behavior, 34, 224230.

Kulm, G., Roseman, J. E., Treistman, M. (1999). A Benchmarks-Based Approach to Textbook Evaluation. Science Books \& Films, 35 (4). Available at: http://www.project2061.org/publications/textbook/articles/approach.htm

Lawrence, Wing Pak Wong. (2011). Textbook Evaluation: A Framework for Evaluating the Fitness of the Hong Kong New Secondary School (NSS) Curriculum. Master's Thesis. Hong Kong: City University of Hong Kong.

Longman dictionary of contemporary English (4th ed.). (2003). Harlow, England: Longman. Masuhara, H. \& Tomlinson, B. (2008). Materials for General English. In B.Tomlinson (Ed), English Teaching Materials: A Critical Review (pp. 17-37). London: Continuum.

McGrath, Ian. (2001). Materials Evaluation and Design for Language Teaching. Edinburgh: Edinburgh University Press.

McGrath, Ian. (2002). Materials Evaluation and Design for Language Teaching. Edinburgh: Edinburgh

Monbec, Laetitia. (2020). Systematic Functional Linguistics for the EGAP Module: Revisiting the Common Core. Journal of English for Academic Purposes, 43: 1-14. https://doi.org/10.1016/j.jeap.2019.100794

Montasser, A. Wahab. (2013). Developing an English Language Textbook Evaluative Checklist. IOSR Journal of Research \& Method in Education, 1(3), 55-70. www.iosrjournal.org.

Mukundan, J., Hajimohammadi, R. and Nimehchisalem, V. (2011). Developing An English Language Textbook Evaluation Checklist. Contemporary Issues in Education Research June 2011. Volume 4, Number 6

Oakey, David. (2020). Phrases in EAP academic writing pedagogy: Illuminating Halliday's influence on research and practice, Journal of English for Academic Purposes, 44. 1-16. https://doi.org/10.1016/j.jeap.2019.100829

Okitasari, I. \& Palupi, D. (2019). Teachers' perceptions toward EFL textbook. ELT in Focus, 2(2), 77-86. 
Patton, M.Q. (2002). Qualitative Research and Evaluation Methods. Thousand Oaks, CA: Sage. Peacock, M. (1997). Choosing the right book for your class. Retrieved from http: //www.sx.ac.uk/linguistics/pgr/egspll/volume1/PDFs/PEACOCK1.pdf

Purwati, Ratna Annisa. (2019). Evaluation on ESP Course Book: Get Along with English for Hotel Industry. Journal of English Educator Society, 4(2), 106-116. DOI: 10.21070/jess.v4i2.2432.

Rahimy, R. (2007). A coursebook evaluation. ESP World, 6, Issue 2(15). Retrieved from http://www.esp-world.info/contents.htm.

Ramadhana, A. Muhammad; Indah Dwi Opik \& Suhardi. (2019). An Evaluation of English Language Textbook: Interlanguage English for Senior High School Students. Jurnal Studi Guru dan Pembelajaran, 2(1), 32-40.

Richards, J. C. (2001). Curriculum development in language teaching. Cambridge: Cambridge University Press.

Sahim, Senem. (2020). Developing a Checklist for English Language Teaching Course Book Analysis. International Journal of Education and Research. 8(1): 107-120. www.ijern.com

Sheldon, L. E. (1988). Evaluating ELT textbooks and materials. ELT Journal, 42(4):237-246.

Solikhah, Imroatus. (2014). Buku Teks Akademik Berbasis Kompetensi untuk Mahasiswa Jurusan Non-Bahasa Inggris (Penelitian dan Pengembangan di Perguruan Tinggi Negeri di Jawa Tengah dan D/Y). Ph.D dissertation. Doctorate Program in Indonesian Language Education. Surakarta: Universitas Sebelas Maret.

Solikhah, Imroatus. (2015). Designing Academic Literacy Framework of EAP Program for Indonesian Learners. Journal of Language and Literature, 6(2): 34-38.

Tesch, R. (1990). Qualitative Research: Analysis Types \& Software Tools. Bristol, PA: Falmer Press.

Ur, P. (1996). A course in language teaching: Practice and theory. Cambridge: Cambridge University Press.

Weber, R. P. (1990). Basic content analysis. Beverly Hills, CA: Sage.

Yapici, Burcin, Org. (2019). Textbook Evaluation in English Language Teaching: Solutions, Preintermediate. KUSAD, 2(1), 62-74.

Zhang, Yan \& Wildemuth, Barbara. (2016). Qualitative Analysis of Content. Available online at:https://www.semanticscholar.org/paper/Qualitative-Analysis-of-Content-by-ZhangWildemuth/b269343ab82ba8b7a343b893815aobae6472fcca. Retrieved on 2 August, 2020. 